\title{
脊椎血管造影術中に生じた一過性皮質盲の症例
}

前田勇 一* 中馬東彦* 清 家一 郎* 堀 内 秀 俊*

\section{A Case Report of Transient Cortical Blindness during Embolization of Veins to Spinal Tumor}

Yuichi Maeda*, Haruhiko Chuma*, Ichiro Seike*, and Hidetoshi Horiuchi*

\begin{abstract}
奉椎腫瘍の術前処置として，腫瘍血管の塞栓術を施行中，一過性皮質盲を生じた症例を経験した。一過 性皮質盲に関する過去の報告では，発症直後の CT や MRI で後頭葉に異常像が見受けられた。我々も CT や MRI を施行したが，特記すべき所見は認められなかった。視力は，4 病日で元に戻り，4 ケ月時 あ変わらなかった，過去の報告と合わせて，この疾患は自然治癒の可能性が高いと思われた.
\end{abstract}

A man suffered transient cortical blindness during embolization of veins to spinal tumor. Immediate MRI showed right putaminal hemorrhage, which was suspected to have been present for a week. $\mathrm{CT}$ on the next day showed nothing. His vision was restored gradually. We suspect that the disorder was self-limiting.

Key words : transient cortical blindness（一過性皮質盲），angiography（血管造影）

\section{はじめに}

血管造影における「一過性皮質盲」の発症は，稀な 合併症である。これらについての報告は, cerebral angiography や coronary angiography でのものが 多く，整形外科領域では，あまり見られない。われわ れは, 脊椎腫瘍による対麻痺症例に対し, 緊急除圧術 を行うべく術前血管塞栓術を施行中，「一過性皮質盲」 を生じた症例を経験したので報告する。

(症例) 61 歳, 男性.

主訴：両下肢が動かない。既往歴：高血圧症.アレ ルギー歴はない.

現病歴：他院に頝部〜肩甲部の痛みと歩行障害にて 入院中, イオベルソール $70 \mathrm{ml}$ による造影胸部・腹部 CT 検查を受けたが，特に変わった事はなかった。平 成 15 年 7 月 6 日に両下肢が動かなくなった。平成 15 年 7 月 8 日, 対麻痺の治療目的にて当科に転院となっ た.

入院時検査所見：Vital sign に異常はなかった。神 経学的には, 左に優位の頚部・肩甲部痛あり。筋力は, 右大腿四頭筋が $[1]$ 以外他は，[0]であった．知覚は，
両乳房近傍が $5 / 10$ でそれ以遠は $0 / 10$ であった。膀 胱・直腸障害有り.

$\mathrm{CEA}$ 高值と, 前医での造影胸部・腹部 CT で直腸 に異常所見があったため, 大腸カメラを施行するも異 常を認めなかった.

MRI : 第二胸椎の椎体圧壊と $\mathrm{T} 1$ 強調像にて脊䯣よ り hyper-intensityな像が有った。

入院後経過：7月 10 日脊椎手術当日, 術前処置と して第 2 胸椎腫瘍の塞栓術を予定した. Feedinng artery を同定後，椎骨動脈から延びている Feedinng arteryにミクロ・カテーテルを入れようとしていた. イオベルソール $20 \mathrm{ml}$ を注入 10 分後より, 前胸部の 痤攣が出現した。以後, 同部の苦しさ・頭痛・意識が 遠のく感じ，さらに「目が見えなくなった.」との訴 えが続いた。我々は, 造影合併症が生じたと判断し, 造影の即時中止と精査・対策を急ぐ事とした.

発症 6 時間後の MRI(図 $1-A)$ にて，皮款出血を認 めたが発症 1 週後とのコメントであった。眼科的には, 異常を認めなかった。ラジカット・ヘパリンにて経過 を観察した.

発症翌日の CT(図 1 -B)にて，特に異常を認めなかっ

* 荒尾市民病院整形外科 Department of Orthopedic Surgery, Arao City Hospital, Kumamoto, Japan 


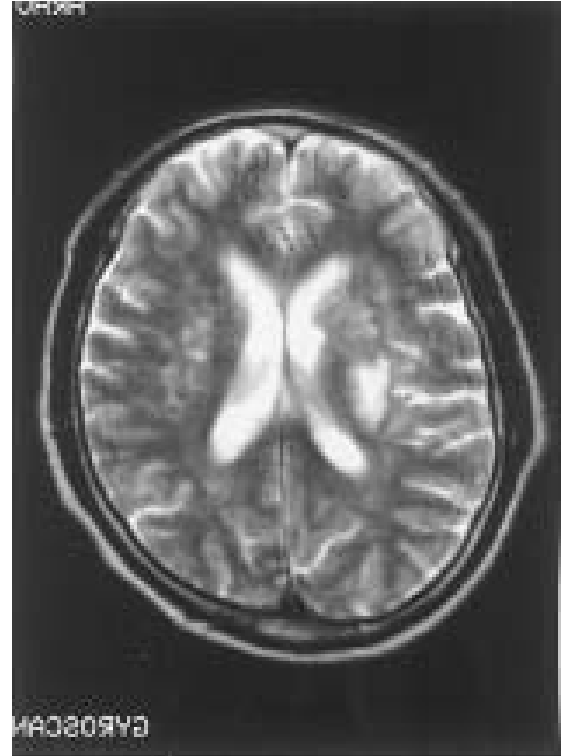

(A)

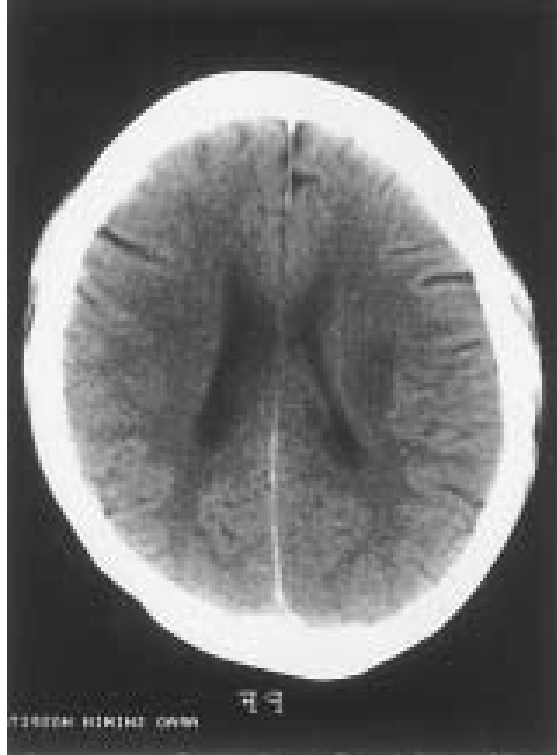

(B)

図 1 (A) MRI (T2w) : 発症 6 時間後に撮影. 右被款に 1 週間前と見られる出血有り. (B) CT：発症翌日に撮影. 特記すべきこと無し.

た。発症 24 時間後より，顔の輪郭位が判り始めた。 以後，視力は，徐々に回復を始め，3 病日にはほぼ回 復したが，とっさの物見が追いつかなかった。4 病日 には，自覚的に元に戻った。 5 病日も变わらず，眼科 的にも異常はなかった.

6 病日朝, 造影合併症は回復をしたと判断し, 除圧・ 固定術を施行した。

術後, 術前の対麻痺が次第に改善し，頸・肩甲部痛 も軽快した。術中組織所見は，H.E.にて紡錘形細胞 が束をなして錯綜し増殖しており，一部車軸状の構造 あ見られた，KP-1では，陽性細胞の浸潤が目立ち， 大型の核を有する細胞の一部屯陽性．以上と他の染色 所見を合わせて MFH の可能性が強かった。11月 11 日緩和医療目的にて転院となる。退院時も視力は，良 好であった。

考察

血管造影における「一過性皮質盲」に関して，1970 年 Wiliams ( $^{9)}$ が coronary angiography 時に生じ たものを報告したのが，初めての報告と思われる，頻 度は, $\operatorname{Lim} \mathrm{KK}^{3)}$ によると, nonionic contrastを用
いた cerebral angiography 時に0.3〜 $1 \%$ ， ionic contrast では $4 \%$ になると報告している。 Vertebral angiography 時には，さらに高頻度になると言われ ている.

「一過性皮質盲」が生じた血管造影は, 報告によると cerebral A.・vertebral A. • brachial A. • aortic arch. • renal A. • coronary A. • translumbar aortography など多岐に渡っていた。整形外科領域に関するもの では, Metrizamide myelography ${ }^{7)} や$ contrastenhanced $\mathrm{CT}^{4)}$ で生じたとする報告むあり，注意が必 要である。

「一過性皮質盲」の診断 ${ }^{2)}$ は，(1)眼球運動異常の無 い視力喪失と (2) Normal fundi (3) Normal papillary reflexes である。

発症は，数分後から 12 時間後までである．随伴症 状は, headaches, mental state changes, memory loss, denial of blindness などである. 予後は良好で, 12 時間までには視力が戻り始め，5日も経つと完全 に回復するという。我々の症例む 4 病日で回復した。

治療は, hydration, heparin, dextran, corticosteroids を使用したとする報告が多いが， 
simple observation ${ }^{5)}$ で良いようである.

素因は，以下の如くと考えられる．Edvinsson L ${ }^{1)}$ によると，椎骨脳底動脈の交感神経支配システムは， 総頸動脈程完全広汎では無い。さらに，重症高血圧の ような，防御的な交感神経を介した動脈血管制御が比 較的弱まるといった要因が加わる事により，椎骨脳底 動脈支配の後側大脳半球に症状が優位に生じる.

成因は，症例によっては vasospasm, cerebral ischemia, cerebral embolism あ否定できない。しか し，CT にて超早期に造影剂が後頭葉を中心に散在す ることや，MRIの diffsion-weighted image で異常 輝度画像が見られないことから，虚血説は比較的否定 的で, neurotoxicity 説が有力である。つまり，血管 造影後に $\mathrm{BBB}$ が破綻 $^{8)}$ し, 造影剤の血管外漏出が生 じ，漏出した造影剤が神経を一時的に障害するあので ある ${ }^{7)}$.

我々の症例では，CT は 1 日後に撮影されたため, この時点では異常像が出現していたとしてもすでに消 失していた可能性が強いと思われた.

\section{結語}

血管造影術中に生じた一過性皮質盲の症例を経験し た. self-limited ${ }^{5)}$ な疾患である可能性が強い.

\section{参 考 文 献}

1) Edvinsson, L., et al. : Automatic nerves, mast cells, and amine receptors in human brain vessels : a histochemical and pharmacological study. Brain Res., 115 : 377-393, 1976.

2) Lantos, G., et al. : Cortical blindness due to osmotic disruption of the blood-brain barrier by angiographic contrastmaterial : CT and MRI studies. Neurology, $39: 567-571,1989$.

3) Lim, K. K., et al. : Transient cortical blindness related to coronary angiographic and graft study. Med. J. Aust., 177 : 43-44, 2002.

4) Mentzel , H. J., et al. : Cortical blindness after Contrast-Enhanced CT. Am. J. Neurol., 24 : 1114-1116, 2003.

5) Saigal, G., et al. : MR finding of cortical blindness following cerebral angiography. Am. J. Neurol., 25 : 252-256, 2004.

6) Schwartz, R. B., et al. : Hypertensive encephalopathy : finding on CT, MR imaging and SPECT imaging in 14 cases. Am. J. Roentgenal., 159 : 379-383, 1992.

7) Smimiotopoulos, J.G., et al. : Cortical blindness after metrizazamide myelography. Arch. Neurol., 41 : 224-226, 1984.

8) Waldrom, R. L., et al. : Effect of contrast media on the blood brain barrier : an electron microscopic study. Radiology, 116 : 195-198, 1983.

9) Wiliams, F. M., et al. : Transient cortical blindness : an unusual complication of coronary angiography. Neurology, 20 : 353-355, 1970. 